\title{
First Record of the European Rusted Flea Beetle, Neocrepidodera ferruginea (Scopoli, 1763), in North America (Coleoptera: Chrysomelidae: Galerucinae: Alticini)
}

\author{
Laurent LeSage and Karine Savard \\ Eastern Cereal and Oilseed Research Center, Agriculture and Agri-Food Canada, K.W. Neatby Building, 960 Carling Avenue, \\ Ottawa, ON, Canada K1A 0C6 \\ Correspondence should be addressed to Laurent LeSage, lesagel@agr.gc.ca
}

Received 1 December 2011; Accepted 4 February 2012

Academic Editor: John Heraty

Copyright ( $) 2012$ L. LeSage and K. Savard. This is an open access article distributed under the Creative Commons Attribution License, which permits unrestricted use, distribution, and reproduction in any medium, provided the original work is properly cited.

The European rusted flea beetle Neocrepidodera ferruginea (Scopoli, 1763) is reported for the first time from Québec and Ontario, Canada. It was likely introduced into southern Ontario at an international port on the Great Lakes in early 1970s, or possibly earlier in the 1960s. However, the exact location and date of introduction could not be precisely determined. The flea beetle has since dispersed northeastwards and reached Aylmer, north of Ottawa River, in Québec, by 2003. This is about $375 \mathrm{~km}$ from Niagara Falls, where the oldest known specimens were collected in 1977. In 2009, various wild habitats and cultivated areas of Aylmer were surveyed. The host plants of the larvae could not be determined, but adults were swept from many plant species including various weeds and cultivated grasses: Alopecurus pratense (meadow foxtail), Dactylis glomerata (orchard-grass), Festuca rubra (red fescue-grass), and Poa pratensis (Kentucky blue-grass). Adults were also collected from flowers of several weeds: Aster sp. (undetermined species), Aster novae-angliae (New England aster), Ambrosia artemisiifolia (small ragweed), Echium vulgare (viper's bugloss), Nasturtium officinale (water cress), Melilotus alba (white sweet-clover), Hypericum perforatum (common St. John's-wort), Lythrum salicaria (purple loosestrife), Ranunculus acris (buttercup), and Solidago spp. (goldenrods). Since larvae are known to develop inside the roots and central stems of cereals, this new alien species represents a threat to Canadian agriculture, particularly if it reaches the Prairies in western Canada, where cereals represent a considerable part of their economy. European rusted flea beetle and Altise ferrugineuse européenne are suggested for the English and French common names of this flea beetle, respectively.

\section{Introduction}

Spectacular and large $(20-35 \mathrm{~mm})$ alien insects such as the Asian longhorn beetle, Anoplophora glabripennis (Motschulsky, 1853), cannot establish themselves unnoticed due to their large size, showy appearance, and the considerable damage they cause to trees. Although much smaller (7$14 \mathrm{~mm}$ ), the Emerald ash borer, Agrilus planipennis Fairmaire, 1888 , was quickly identified by its bright metallic green color and evident damage to ornamental ash (Fraxinus spp.) trees. In contrast, decades may pass before small species are detected, and it may take even longer if they are not associated with economically important plants of horticultural, agricultural, or forestry value. The European flea beetle, Neocrepidodera ferruginea [1], is such a species. Its small size $(3-4 \mathrm{~mm})$ and rusty color contributed to hide it within the vegetation. In addition, the lack of regular insect monitoring in agricultural lands of eastern Canada or of surveys in natural habitats also explain in part why it has been thriving unnoticed for over 30 years. Consequently, the present communication provides information on its identification, habitats, biology, host plants, economic importance, and history of introduction into North America.

\section{Material and Methods}

The specimens collected by the authors were obtained using the technique of LeSage [2].

The habitus photograph was taken using a digital Leica DFC-420 camera mounted on a Leica MZ-16 dissecting 
microscope. The male aedeagus was photographed with an image processing system composed of a Nikon SMZ-1500 stereoscopic microscope coupled to a Nikon Digital camera DXM-1200F. The final image treatment was made with Photoshop Elements 7.0 software. The female genitalic features were dissected in 75\% ethanol, preserved in terpineol, positioned on a microscope slide, and photographed with a Nikon Coolpix 950 digital camera attached to a Nikon Eclipse E-800 compound microscope.

\section{Nomenclature}

Originally described as Chrysomela ferruginea by Scopoli [1], this species was transferred to the flea beetle genus Altica by Geoffroy [3], but in the eighteenth century, the "genus" concept was so broad that it included all contemporary flea beetles. In the second edition of the catalogue of the beetles preserved in the collection of count Dejean, Chevrolat [4] split the large genus Altica into several new genera including Crepidodera under which he listed C. ferruginea, but did not designate a type species for the genus. The generic description itself appeared seven years later in the universal dictionary of d'Orbigny [5] mainly based on a transverse furrow on the pronotum and elytral punctures arranged in rows. Foudras [6] fragmented the original Crepidodera into six genera using new taxonomic characters and designated Chrysomela nitidula Linnaeus, 1758 as the type species of Chalcoides, one of his new genera. According to Biondi [7], Maulik [8] was not aware of this designation and designated the same species (nitidula) as the type species of Chalcoides Foudras with the result that species previously placed in Crepidodera sensu Foudras had to be transferred to Asiorestia created by Jakobson [9]. For the following sixty years, the species ferruginea was cited by authors in this genus. Exhaustive lists of references can be found in Biondi [10] and Gruev and Döberl [11, 12], and a detailed history of Asiorestia in Biondi [7]. The last nomenclatorial change happened when Konstantinov and Vandenberg [13] established the synonymy of Asiorestia Jakobson, 1926 with the genus Neocrepidodera created by Heikertinger [14] to include in a new generic unit, a Siberian flea beetle, Ochrosis sibirica, described by Pic [15], and the Japanese Crepidodera recticollis described by Jacoby [16]. Consequently, the official current name of the species treated here is Neocrepidodera ferruginea [1].

The early French entomologist Geoffroy [3] and Fourcroy [17] referred to Neocrepidodera ferruginea as the "Altise fauve à stries" on the basis of its elytral punctures arranged in rows, whereas Olivier [18] and du Chatenet [19] named it "Altise ferrugineuse" based on the typical reddish brown color of this flea beetle. In England, Shaw [20] and Jones and Jones [21] reported it as the "Wheat flea beetle." Davies [22] used a more specific name: the "Wheat stem flea beetle."

Adults are polyphagous and larvae attack several cultivated cereals $[10,19,23-25]$. Consequently, it might be confusing, even erroneous, to assign a popular name on the basis of a single host plant. On the other hand, the body color is typical and unusual, at least among the North American flea beetle fauna, although such rusted color is also found in

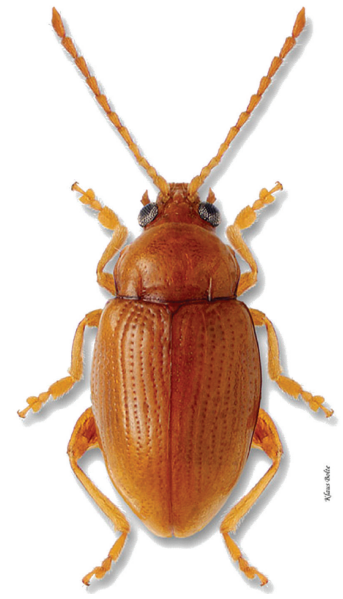

Figure 1: Neocrepidodera ferruginea, dorsal habitus. Body length, $3.5 \mathrm{~mm}$, excluding antennae.

other species of the Old World. For these reasons, we follow Olivier [18] and suggest "European rusted flea beetle" and "Altise ferrugineuse européenne," respectively for the English and French common names of N. ferruginea. We have added a reference to the origin of the beetle to indicate that it is an alien species for North America.

\section{Identification}

Several recent publications are available for the identification of Neocrepidodera at generic level. In North America, Riley et al. [26] provided the most recent synthesis of the North American leaf beetles including a key to Neocrepidodera and all other flea beetle genera of this continent. In the Old World, the handbook of Konstantinov and Vandenberg [13], and the keys of Warchalowski [27], are excellent tools for the identification of the Palaearctic fauna. The European and Mediterranean fauna were treated by Warchalowski [28], the fauna of Britain and Ireland by Cox [24], and the flea beetles of France by Doguet [29]. Species in the N. ferruginea group were recently revisited by Baselga and Novoa [30] including the illustration of their spermatheca and styli (vaginal palpi) for all treated species.

The characters most often used in generic keys are antennae 11-segmented, antennal calli raised and oval, pronotum transverse, narrowly explanate laterally, pronotal antebasal transverse impression present as well as a pair of lateral longitudinal furrows, elytral punctures generally arranged in regular rows, no hairs on elytra, procoxal cavities closed behind, and metatarsal claws not strongly inflated.

At the specific level, the diagnostic characters of Neocrepidodera ferruginea are as follows. Length of adult, 2.6$3.7 \mathrm{~mm}$. Color uniformly yellowish brown to rusty brown (Figure 1). Frontal carina broad and low, frontal tubercles triangular, and not delineated posteriorly by a groove. Ocular groove behind eyes present. Frons and vertex smooth. Pronotum transverse, laterally margined; anterior angles large, protruding, bearing large seta; microsculpture finer on disk, coarser at basal groove; basal transverse groove 


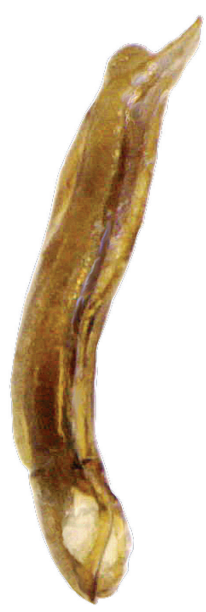

(a)

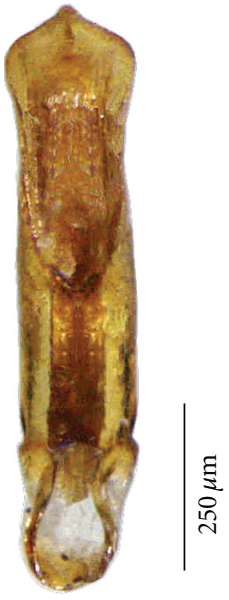

(b)
Figure 2: Neocrepidodera ferruginea, male aedeagus: (a) lateral view; (b) ventral view.

moderately deep, lateral longitudinal furrows deep. Elytra tapering at apex; elytral punctures large, deep, in regular rows, sometimes partially duplicated or disordered near suture; humeral callus well developed. Species fully winged. In the male, first tarsal segment of front and median legs markedly broadened (Figure 1). Sides of male aedeagus subparallel in dorsal view with apex triangular, slightly nipple-shaped in middle (Figure 2(b)); tip slightly upright in lateral view (Figure 2(a)); ventral median membranous portion almost reaching base. Female spermatheca elongate, slightly ovoid at base, spermathecal pump cylindrical and bent at $90^{\circ}$, spermathecal duct not coiled, bent at $45^{\circ}$ to the median axis of the spermathecal pump (Figure 3(a)). Styli moderately short and thick, fused at base, tapered and pointed at apex (Figure 3(b)).

The body color of the native North American Neocrepidodera robusta (Leconte, 1874) is deep red, whereas N. ferruginea is brownish yellow (Figure 1). The antennomeres of the former are shorter and thicker than those of the latter. The elytra of the former are not tapered at the apex as they are in the latter. Neocrepidodera robusta has been reported from Québec to British Columbia and in Newfoundland [32, 33], but specimens are rare in collections examined. Those from Québec and Ontario, preserved in the CNC, were all collected in northern localities of these provinces and not in southern localities as is the case for $N$. ferruginea.

The larva of Neocrepidodera ferruginea was described in detail by Blunck [23] and included in keys by Oglobin and Medvedev [34], Medvedev and Zaitsev [35], and Steinhausen $[36,37]$. These keys are largely based on the number, position, and chaetotaxy of the tergites. According to these authors, the larva of Neocrepidodera ferruginea is yellowish-white with dark-brown head, legs, and thoracic and abdominal tergites. The epicranial suture is Y-shaped, the coronal stem short, only one-third the length of the head. There are 6 setae on the frons and 10 on the vertex. One ocellum is present near the base of each antenna, but only

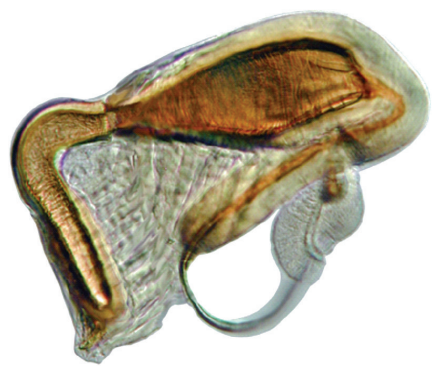

(a)

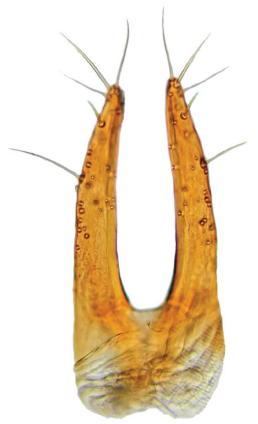

(b)
FIGURE 3: Neocrepidodera ferruginea, female genitalia: (a) spermatheca; (b) styli (vaginal palpi).

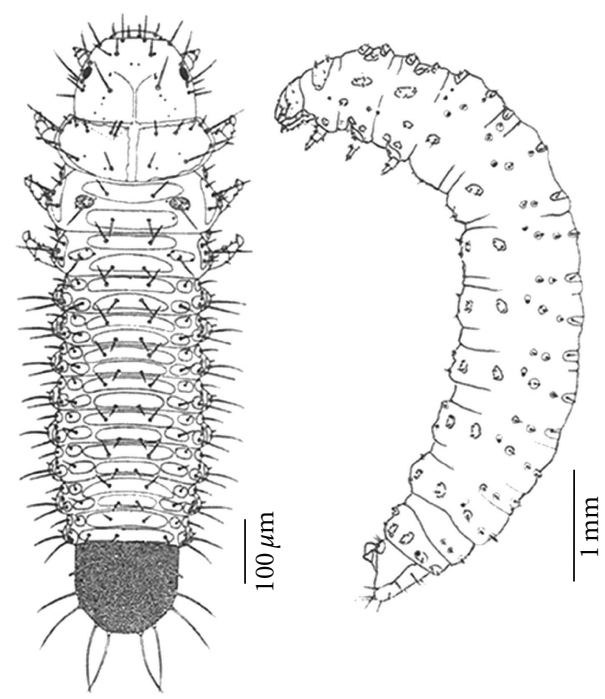

Figure 4: Neocrepidodera ferruginea, habitus of larva: (a) dorsal view; (b) lateral view. Modified from Blunck [23].

in the first instar larvae. The antennae are 2-segmented. The maxillary palpi are 3-segmented and the labial are palpi 2segmented. The pronotum bears 10 setae on its anterior margin, 6 on the posterior margin. The last (9th) abdominal tergite forms a plate bearing 8 marginal and 4 discal setae; the whole surface is covered with an alveolar microsculpturing (Figures 4(a) and 4(b)). The pupa is still undescribed. The egg was sketched by Blunck [23], and its rough hexagonal microsculpture was illustrated, but its distinctive fine microsculpture was not shown (Figure 5).

\section{Introduction into North America}

During the winter of 2008, a small yellowish flea beetle was found in a pitfall trap from an alvar (limestone plain) of Aylmer (Québec). It was an unusual flea beetle for the local fauna. Comparisons with European specimens of similar appearance exchanged with the late French entomologist Michel Bergeal [25] convinced us that this specimen was identical to the Palaearctic $N$. ferruginea. During the summer 


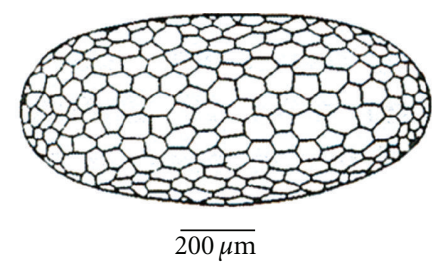

Figure 5: Neocrepidodera ferruginea, egg (after Blunck [23]).

of 2009, several natural and agricultural open habitats of Aylmer were surveyed in order to collect more specimens. The unsorted and unidentified holdings of the Canadian National Collection (CNC) were also examined, and eleven specimens were found: two were mixed with the miscellaneous Newfoundland flea beetles donated by Dave Larson (formerly at Memorial University, St. John's), nine were found in the unsorted beetles of the Carr's collection recently bequested to the CNC. Additional specimens received in the 1990s from S.A. Marshall (Guelph University), are also included in the present communication.

The date and place of these insect specimens are the most important clues to determining the history of introduction of this alien species. As concerning Neocrepidodera ferruginea, the oldest voucher specimens available were collected in 1977, but this species must have been thriving many years before this date. For instance, the lily leaf beetle, Lilioceris lilii [1] (Criocerinae), a bright red-bodied beetle with black head and appendages, was first detected in Montréal in 1943, but persisted at low levels for 30 years before expanding on the island of Montréal and making a noticeable jump to Ottawa by $1981[38,39]$. It reached Nova Scotia in 1992, Toronto (Ontario) in 1993, and Portage la Prairie (Manitoba) in 2003 [40, 41]. Another pest, the cereal leaf beetle, Oulema melanopus (Linnaeus, 1758) (Criocerinae), is suspected to have been introduced into North America between 1947 and 1949, but was detected and positively identified only in 1962 from Berrien Co., in Michigan [42-44]. These case studies lead us to believe that $N$. crepidodera may have gone through a similar introduction and distribution pattern, survived at low numbers for many years, and only commenced longrange dispersal when high population levels were reached. The two 1977 specimens collected at Niagara Falls represent the beginning of the population expansion phase. This locality is probably not the original site of introduction which is more likely an international port located on one or the other Great Lakes.

\section{Distribution}

According to the Catalogue of Palaearctic Coleoptera of Löbl and Smetana [31], the distribution of Neocrepidodera ferruginea includes the Azores, all of Europe, except Iceland, the European parts of Russia, Asia Minor, Iran, and Turkey (Figure 6). It could also be present in Armenia, but no published records are available, and this needs to be confirmed. However, according to Gruev and Döberl [11, 12], Corsica, Egypt, Morocco, Siberia, and West Turkestan are doubtful records.

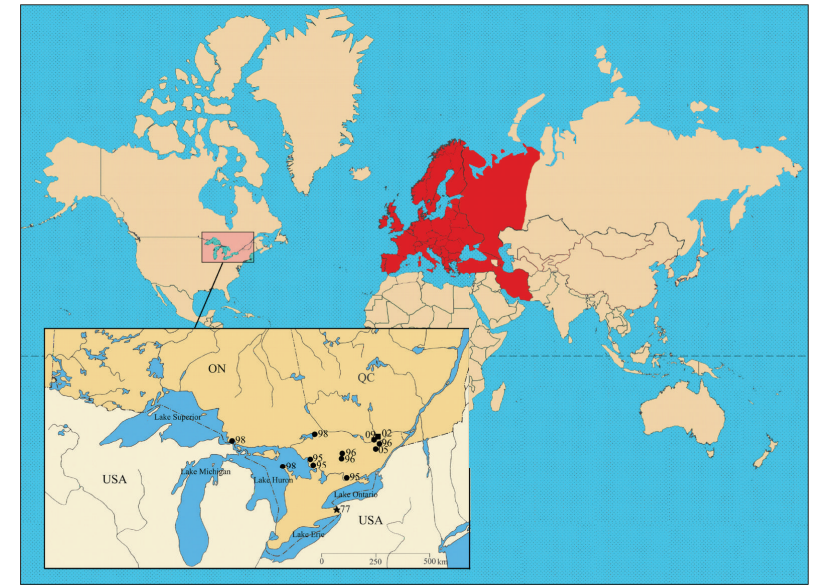

FIgURE 6: Old World distribution of Neocrepidodera ferruginea according to the countries listed in the catalogue of Löbl and Smetana [31]. Insert: distribution of Neocrepidodera ferruginea in North America. Star: Niagara Falls (Ontario), where the first specimens were collected. Solid circles: collection localities with collection years of 77 (1977) 95 (1995), 96 (1996), 98 (1998), 02 (2002), and 05 (=2005). Solid square: all collections in Aylmer (Québec) grouped together.

In North America, $N$. ferruginea is currently known from southern Ontario, and southwestern Québec on the north shore of the Ottawa River (inserted in Figure 6). The collection data of these new locations are as follows.

Material Examined. Canada: Québec: Gatineau/Aylmer $\left(45^{\circ} 24^{\prime} \mathrm{N}, 75^{\circ} 50^{\prime} \mathrm{W}\right)$ : Baillie street (north), 28.VII.2009, L. LeSage, border of Breckenridge stream on Solidago spp., grasses, and so forth, general sweeping [CBUM] 2; [CFIM] 2; [CNC] 3; Boucher Forest (north-east), north path, eastwest, 16.VIII.2009, L. LeSage, on Rhus radicans, and so forth, general sweeping [CBUM] 1; [CNC] 1; Boucher Forest (west), 11.VIII.2009, L. LeSage, under Hydro-Québec electric line, on flowers of Ambrosia sp., Solidago spp., Daucus sp., Melilotus sp., general sweeping [CBUM] 3; [CFIM] 1; [CNC] 2; Boucher road (north), 8.VIII.2009, L. LeSage, in waste land on flowers of Solidago spp., Melilotus sp., Daucus sp., Aster spp, Ambrosia sp., and so forth, general sweeping, [CBUM] 1; [CNC]1; Boucher/Klock roads (north-east), close to transmission tower, 21.VII.2009, L. LeSage, waste land, on Daucus sp., Solidago spp., Lythrum sp., Salix sp., Scirpus sp., Melilotus sp., and so forth, general sweeping [CNC] 1; (north-west), 14.VIII.2009, L. LeSage, waste land, grasses, Scirpus sp., Daucus sp., Solidago spp., Melilotus sp., and so forth, general sweeping $[\mathrm{CBUM}] 1$; $[\mathrm{CNC}] 1$; Chagnon street (east), 18.VII.2010, V. Théberge, close to Hydro-Québec electricity line, on grass [CNC] 1; Cook road (north), 2.VII.2009, L. LeSage, ditch between two pastures on Lythrum sp., Nasturtium sp., Ranunculus sp., Scirpus sp., Echium sp., Daucus sp., and so forth general sweeping [CBUM] 1; [CFIM] 1; [CNC] 1; 16.VII.2009, L. LeSage, ditch between two fields on Nasturtium, and so forth, general sweeping [CNC] 1; 5.VIII.2009, L. LeSage, ditch between two fields on Nasturtium officinale, Scirpus sp., general sweeping 
[CBUM] 2; [CFIM] 2; [CNC] 2; 5.VIII.2009, L. LeSage, pasture, Echium vulgare flowers, Daucus carota, grasses, and so forth, general sweeping [CBUM] 1; [CFIM] 1; [CNC] 1; west of Cook dump, 17.VII.2009, L. LeSage, Daucus sp., flowers, Melilotus sp., Hypericum sp., and so forth, general sweeping [CFIM] 1; [CNC] 1; Cook road (south), 21.VII.2009, L. LeSage, close to pound with Equisetum sp., Daucus carota flowers, Solidago spp., grasses, and so forth, general sweeping [CBUM] 2; [CNC] 1; 25.VII.2009, L. LeSage, fallow field on limestone, Asclepias syriaca, Solidago spp., Hypericum sp., grasses, and so forth, general sweeping [CBUM] 3; [CFIM] 1; [CNC] 2.; 25.VII.2009, L. LeSage, fallow field on limestone, Asclepias sp., Apocynum sp., Solidago spp., grasses, and so forth, general sweeping [CBUM] 1; [CFIM] 1; [CNC] 1; Pink road (south), near Museum of Nature, path north-south, 26.VII.2009, L. LeSage, abandoned field, Lythrum salicaria, grasses, and so forth, general sweeping [CBUM] 1; [CFIM] 1; [CNC] 1; Pink/Scholle roads, 25.VII1.VIII.2006, L. LeSage, alvar, burned cedar forest of origin, on limestone, yellow pan trap [CNC] 1; 31.VII.2009, L. LeSage, alvar, Daucus carota flowers, Solidago spp., Hypericum sp., Melilotus sp., grasses, and so forth, general sweeping [CBUM] 2; [CFIM] 1; [CNC] 1; Principale street (north), around Golf La Croisée, 30.VII.2009, L. LeSage, Daucus sp. flowers, Arctium sp., Solidago spp., grasses, and so forth, general sweeping [CBUM] 4; [CFIM] 2; [CNC] 2; 30.VII.2009, L. LeSage, around a containment basin, Daucus sp., Arctium sp., Solidago spp., grasses, and so forth, general sweeping [CBUM] 8; [CFIM] 2; [CNC] 3; Simmons street (south), 7.VII.2007, L. LeSage, cleared space for future street, small stand of Plantago major, general sweeping $[\mathrm{CNC}] 1$; 27.VIII.2009, L. LeSage, clearing in mixed forest, on limestone, grasses, Solidago spp., sweeping, LL03-39 [CBUM] 2; [CFIM] 1; [CNC]; Vanier/Pink roads (north), north Mountain View church, 29.VII.2009, L. LeSage, abandoned field, grasses, Solidago spp. flowers, Asclepias sp., and so forth, general sweeping [CBUM] 4; [CFIM] 1; [CNC] 6; Vernon street (north), tributary of Lac des Fées, 1.VIII.2003, L. LeSage, border of creek, Lythrum salicaria, sweeping, LL0385 [CNC] 1. Gatineau Park $\left(45^{\circ} 34^{\prime} \mathrm{N}, 75^{\circ} 57^{\prime} \mathrm{W}\right): 1 \mathrm{~km}$ south of Ramsay Lake, 19.VIII.2009, L. LeSage, forest path, toward [Eardley] Escarpment, general sweeping [CNC] 1. Ontario: Algoma District $\left(48^{\circ} 00^{\prime} \mathrm{N}, 84^{\circ} 00^{\prime} \mathrm{W}\right)$ : Sault Sainte-Marie, 29.VI.1998, R. Atkinson [CNC] 4; Bruce Co. $\left(44^{\circ} 18^{\prime} \mathrm{N}, 81^{\circ} 25^{\prime} \mathrm{W}\right)$ : Dunks Bay, $45.14 \mathrm{~N} ; 81.38 \mathrm{~W}$, 30.VII.1998, S.A., Marshall [CNC] 1; 20.VII.-1.IX.1999, S.A., Marshall, on shoreline, Malaise [CNC] 2; [SAMC] 3; 15.XI.1999-15.III.2000, S.A., Marshall, Lake edge, Malaise [SAMC] 1; 23-27.VII.2000, S.A., Marshall [CNC] 1; Dorcas Bay, VII.1998, S.A., Marshall, alvar [SAMC] 1; 16.VII2.VIII.1999, S.A., Marshall, in pound behind dune, Malaise [SAMC] 1; Cameron Lake Road South, 20-29.VII.1999, S.A., Marshall, spring fen, pan trap [SAMC] 1; Georgian Bay, Fathom Five National Park, 25.VI-28.VII.1995, T. Woodcock \& S. Marshall, Land Base Cedar Duff, pan trap [CNC] 1; [SMAC] 1; Hastings Co. $\left(44^{\circ} 45^{\prime} \mathrm{N}, 77^{\circ} 40^{\prime} \mathrm{W}\right)$ : Baptiste Lake, 10.VII.1995, B.F. \& J.L. Carr [CNC] 3; Maynooth, 17.VII.1996, B.F. \& J.L. Carr [CNC] 1; Cardiff, 22.VII.1996, B.F. \& J.L. Carr [CNC] 1; Highway 69, $2 \mathrm{~km}$ north of Nobel,
23.VI.1996, B.F. \& J.L. Carr [CNC] 1; Welland Co. $\left(43^{\circ} 05^{\prime}\right.$ N, 79 $04^{\prime}$ W): Niagara Falls, 23.VII.1977, D. Larson [CNC] 2; Carleton Co. $\left(45^{\circ} 15^{\prime} \mathrm{N}, 75^{\circ} 45^{\prime} \mathrm{W}\right)$ : Stittsville, 5.VII.2005, Envirocontrol, Topsoil (large number) [CNC] 4. Nepean, 2.VII.1996, B.F. \& J.L. Carr [CNC] 1; Nepean, 4.VII.1996, B.F. \& J.L. Carr [CNC] 1; Parry Sound District $\left(45^{\circ} 45^{\prime} \mathrm{N}, 79^{\circ} 50^{\prime}\right.$ W): Parry Sound, 12.VII.1995, B.F \& J.L. Carr [CNC] 1.

\section{Habitats}

Neocrepidodera ferruginea has been reported from a large variety of habitats or sites. Medvedev and Zaitsev [35] stated that it was found on wet meadows, bogs, and cereal fields in Siberia and the Russian Far East. In France, Doguet [29] mentioned fallow fields, roadsides, cultivated areas, natural prairies, and so forth. In his guide of the leaf beetles of Europe, du Chatenet [19] reported it from fields, prairies, and fallows. In Britain and Ireland, Cox [24] listed woodland, downland, heathland, moorland, commons, arable land, setaside, gardens, roadside verges, pits, quarries, sea walls, and dunes. In Québec (Aylmer), specimens were collected in alvars, abandoned fields, pastures, vacant lots, ditches, edges of creek, limestone outcrops, and forest trails. According to the Watford Coleoptera Group [45], meadows and wet meadows are the biotopes of this flea beetle in Britain.

\section{Biology}

Little is known on the biology of Neocrepidodera ferruginea in North American except for the habitats, where it was collected. In Europe, there has been few additional publications published since the pioneering work of Blunck [23]. According to this author, adults emerge in June in Germany, but earlier in warmer climates. They mate and lay eggs in summer and fall. Females deposit their eggs in the ground beside the seeds of potential host plants. The young larvae enter seedlings at the host's base and later excavate tunnels throughout their roots and central stems [46]. Larval development extends into the winter, but as temperature decreases, larvae leave their host plants, move deeper into the ground, and overwinter in the soil. They become active again the next spring as the top soil thaws after which they search for new host plants to complete their development. Pupation occurs underground in earthen cells and lasts 2-3 weeks. They become fully developed by the end of May or the beginning of June. There is only one generation per year (univoltine) in Germany.

\section{Host Plants}

Although dozens of "hosts" were reported for the adults of Neocrepidodera ferruginea, quite a few are probably no more than incidental presences of the beetle on such plants since larval development has been observed only in a few species of Poaceae. Blunck [23] tested over 40 potential hosts and estimated that half of them were markedly used or preferred by the adults in some 20 plant families (Table 1). Thistles (Carduus spp. and Cirsium spp.) are the most frequently cited hosts for adults: Bedel [47], Balachowsky and Mesnil [48], 
TABle 1: Most important lists of recorded host plants for Neocrepidodera ferruginea. The list of Blunck [23] includes only the first two categories.

\begin{tabular}{|c|c|c|c|c|c|c|c|c|}
\hline Family & Latin names & Popular names & $\begin{array}{c}\text { Blunck } \\
1932 \\
{[23]} \\
\end{array}$ & $\begin{array}{c}\text { Biondi } \\
1982 \\
{[51]} \\
\end{array}$ & $\begin{array}{c}\text { Doguet } \\
1989\end{array}$ & $\begin{array}{c}\text { du } \\
\text { Chatenet } \\
2002[19]\end{array}$ & $\begin{array}{l}\text { Cox } \\
2007 \\
{[24]} \\
\end{array}$ & $\begin{array}{c}\text { LeSage/Savard } \\
2011\end{array}$ \\
\hline Anacardiaceae & Rhus radicans $\mathrm{L}$. & Poison ivy & & & & & & $\mathrm{X}$ \\
\hline Apiaceae & Daucus carota L. & Wild carrot & & & & & & Flowers \\
\hline Apocynaceae & Apocynum androsaemifolium $\mathrm{L}$. & Spreading dogbane & & & & & & $\mathrm{X}$ \\
\hline Asclepiaceae & Asclepias syriaca $\mathrm{L}$. & Milkweed & & & & & & $\mathrm{X}$ \\
\hline Asteraceae & (species not specified) & Composite family & & & & $\mathrm{X}$ & & $\mathrm{X}$ \\
\hline Asteraceae & Aster spp. & Aster & & & & & & Flowers \\
\hline Asteraceae & Aster novae-angliae L. & New England aster & & & & & & Flowers \\
\hline Asteraceae & Ambrosia artemisiifolia $\mathrm{L}$. & Small ragweed & & & & & & Flowers \\
\hline Asteraceae & Artemisia vulgaris $\mathrm{L}$. & Mugwort & $\mathrm{XX}$ & & $\mathrm{X}$ & & & \\
\hline Asteraceae & Carduus sp. & Thistle & & & $\mathrm{X}$ & & & \\
\hline Asteraceae & Carduus acanthoides L. & $\begin{array}{l}\text { Plumeless nodding } \\
\text { thistle }\end{array}$ & & $\mathrm{X}$ & & & & \\
\hline Asteraceae & Carduus nutans L. & Musk thistle & & $\mathrm{X}$ & & & & \\
\hline Asteraceae & Centaurea acaulis Willd. & Dwarf thistle & $\mathrm{XX}$ & & & & & \\
\hline Asteraceae & Centaurea cyanus L. & Corn flower & $\mathrm{XX}$ & & $\mathrm{X}$ & & & \\
\hline Asteraceae & Centaurea scabiosa L. & Greater knapweed & $\mathrm{XX}$ & $\mathrm{X}$ & $\mathrm{X}$ & & & \\
\hline Asteraceae & $\begin{array}{l}\text { Chrysanthemum } \\
\text { leucanthemum L. }\end{array}$ & Daisy & $\mathrm{Xx}$ & & & & $\mathrm{X}$ & \\
\hline Asteraceae & Cirsium arvense Scop. & Canada thistle & & $\mathrm{X}$ & & & & \\
\hline Asteraceae & Cirsium canum Moench. & Queen Anne's thistle & & $\mathrm{X}$ & & & & \\
\hline Asteraceae & Cirsium lanceolatum Hill.* & Spear thistle & & $\mathrm{X}$ & & & & \\
\hline Asteraceae & Cirsium oleraceum L. & Cabbage thistle & $\mathrm{XX}$ & & $\mathrm{X}$ & & & \\
\hline Asteraceae & Silybum marianum Gaertn. & Milk thistle & $\mathrm{XX}$ & & $\mathrm{X}$ & & & \\
\hline Asteraceae & Solidago spp. & Goldenrod & & & & & & Flowers \\
\hline Asteraceae & Taraxacum officinale Weber & Dandelion & $\mathrm{XX}$ & & $\mathrm{X}$ & & & \\
\hline Boraginaceae & (species not specified) & Borage family & & & & $\mathrm{X}$ & & \\
\hline Boraginaceae & Borago officinalis L. & Borage & $\mathrm{XX}$ & & & & $\mathrm{X}$ & \\
\hline Boraginaceae & Echium vulgare L. & Viper's bugloss & & & & & & Flowers \\
\hline Boraginaceae & Symphytum officinale L. & Comfrey & & $\mathrm{X}$ & & & & \\
\hline Boraginaceae & Symphytum sp. & Comfrey & $\mathrm{XX}$ & & & & $\mathrm{X}$ & \\
\hline Brassicaceae & Brassica napus L. & Rape & $\mathrm{X}$ & & & & & \\
\hline Brassicacae & Brassica oleracea L. & Cabbage & $\mathrm{Xx}$ & & & & $\mathrm{X}$ & \\
\hline Brassicacae & Brassica rapa $\mathrm{L}$. & Wild turnip & $\mathrm{Xx}$ & & & & & \\
\hline Brassicacae & Nasturtium officinale R. Br. & Water cress & & & & & & Flowers \\
\hline Cannabaceae & Cannabis sativa $\mathrm{L}$. & Hemp & & & $\mathrm{X}$ & $\mathrm{X}$ & & \\
\hline Compositae & Achillea millefolium $\mathrm{L}$. & Common yarrow & $\mathrm{Xx}$ & & & & flowers & \\
\hline Cyperaceae & Scirpus sp. & Bulrush & & & & & & $\mathrm{X}$ \\
\hline Equisetaceae & Equisetum sp. & Horsetail & & & & & & $\mathrm{X}$ \\
\hline Fabaceae & (species not specified) & Pulse family & & & & $\mathrm{X}$ & & \\
\hline Fabaceae & Melilotus alba Medik. & White sweet-clover & & & & & & Flowers \\
\hline Fabaceae & Onobrychis sp. & Sanfoins (“sainfoins") & & & $\mathrm{X}$ & & & \\
\hline Fabaceae & Pisum sativum $\mathrm{L}$. & Peas & & & & & $\mathrm{X}$ & \\
\hline Fabaceae & Trifolium sp. & Clover & & & $\mathrm{X}$ & & & \\
\hline Fabaceae & Vicia sp. & Vetch & & & $\mathrm{X}$ & & & \\
\hline Hypericaceae & Hypericum perforatum L. & Common St. John's-wort & & & & & & Flowers \\
\hline
\end{tabular}


Table 1: Continued.

\begin{tabular}{|c|c|c|c|c|c|c|c|c|}
\hline Family & Latin names & Popular names & $\begin{array}{c}\text { Blunck } \\
1932 \\
{[23]}\end{array}$ & $\begin{array}{c}\text { Biondi } \\
1982 \\
{[51]}\end{array}$ & $\begin{array}{c}\text { Doguet } \\
1989\end{array}$ & $\begin{array}{c}\mathrm{du} \\
\text { Chatenet } \\
2002[19]\end{array}$ & $\begin{array}{l}\text { Cox } \\
2007 \\
{[24]}\end{array}$ & $\begin{array}{c}\text { LeSage/Savard } \\
2011\end{array}$ \\
\hline Lamiaceae & Lamium sp. & Dead-nettle & & & & & $\mathrm{X}$ & \\
\hline Lythraceae & Lythrum salicaria $\mathrm{L}$. & Purple loosestrife & & & & & & Flowers \\
\hline Poaceae & (species not specified) & Cultivated cereals & $\mathrm{XX}$ & $\mathrm{X}$ & $\mathrm{X}$ & $\mathrm{X}$ & $\mathrm{X}$ & \\
\hline Poaceae & (species not specified) & Wild grasses & $\mathrm{XX}$ & & & $\mathrm{X}$ & $\mathrm{X}$ & $\mathrm{X}$ \\
\hline Poaceae & Avena sativa $\mathrm{L}$. & Oats & $\mathrm{XX}$ & & & & & \\
\hline Poaceae & Bromus sp. & Brome grass & & & $\mathrm{x}$ & & & \\
\hline Poaceae & Cynosurus sp. & Dog's tail & & & $\mathrm{x}$ & & & \\
\hline Poaceae & Dactylis sp. & Orchard grass & & & $\mathrm{x}$ & & & \\
\hline Poaceae & Festuca sp. & Fescue grass & & & $\mathrm{x}$ & & & \\
\hline Poaceae & Hordeum vulgare $\mathrm{L}$. & Barley & $\mathrm{XX}$ & & $(\mathrm{X})$ & & & \\
\hline Poaceae & Lolium sp. & Ryegrass & & & $\mathrm{x}$ & & & \\
\hline Poaceae & Phalaris sp. & Canary grass & & & & & & \\
\hline Poaceae & Phleum pratense $\mathrm{L}$. & Timothy & & & & & & $\mathrm{x}$ \\
\hline Poaceae & Poasp. & Bluegrass & & & $\mathrm{x}$ & & & \\
\hline Poaceae & Secale cereale $\mathrm{L}$. & Rye & $\mathrm{XX}$ & & & & & \\
\hline Poaceae & Triticum vulgare Vill.** & Wheat & $\mathrm{XX}$ & & & & & \\
\hline Polygonaceae & (species not specified) & Buckwheat family & & & $\mathrm{X}$ & $\mathrm{X}$ & & \\
\hline Polygonaceae & Polygonum sp. & Knotweed & $\mathrm{XX}$ & & & & $\mathrm{x}$ & \\
\hline Ranunculaceae & Ranunculus acris $\mathrm{L}$. & Buttercup & & & & & & Flowers \\
\hline Salicaceae & Salix sp. & Willow & & & & & & X \\
\hline Urticaceae & Urtica dioica L. & Stinging nettle & $\mathrm{XX}$ & $\mathrm{X}$ & & & & \\
\hline Urticaceae & Urtica sp. & Nettle & & & $\mathrm{x}$ & $\mathrm{X}$ & $\mathrm{X}$ & \\
\hline
\end{tabular}

$\mathrm{X}$ : used

XX: strongly used

$\mathrm{Xx}$ : more or less used

(X): plant species doubtful

* Cirsium lanceolatum currently considered synonym of Cirsium vulgare (Savi) Ten. [58].

** Triticum vulgare currently considered synonym of Triticum aestivum L. [59].

and Doguet [29] in France; Lameere [49] in Belgium; Blunck [23] in Germany; Joy [50] in England; Ogloblin and Medvedev [34] in the European part of Ru

ssia of the past USSR, Medvedev and Zaitsev [35] in Siberia and the Russian Far East; Biondi [51], in Italy; Gruev and Tomov [52] in Bulgaria; Warchalowski [28] in Europe and Asia; Gök and Çilbiroğlu [53] in Turkey; Bukejs [54] in Latvia. Nettles (Urtica spp.), or more precisely the stinging nettle (Urtica dioica L.), are the next most frequently given hosts: Kutschera [55] for Europe; Allard [56] for Austria, Favre [57] for France; Joy [50] for England; Ogloblin and Medvedev [34] European part of USSR, Medvedev and Zaitsev [35] for Siberia and the Far East; Biondi [51] for Italy; Doguet [29] for France; du Chatenet [19] for Europe; Cox [24] for Britain and Ireland.

In addition to thistles and nettles, grasses are economically important hosts reported by many authors. According to Blunck [23], barley, rye, and wheat were frequently used. Doguet [29] listed blue-grass (Poa sp.), brome-grass (Bromus sp.), dog's tail (Cynosurus sp.), fescue-grass (Festuca sp.), orchard-grass (Dactylis sp.), and rye-grass (Lolium sp.), but did not specify a preference. du Chatenet [19] and Cox [24] referred to cultivated and wild grasses in general without mentioning a peculiar variety. During our 2009 survey four species appeared most common: Kentucky blue-grass (Poa pratensis), meadow foxtail (Alopecurus pratensis), orchardgrass (Dactylis glomerata), and red fescue-grass (Festuca rubra). Voucher specimens of these grasses are deposited in DAO herbarium in Ottawa.

Flowering weeds were also surveyed because they could easily be identified in pastures and fields while sweeping. The viper's bugloss, or blueweed, (Echium vulgare) cannot be missed with its numerous bright blue flowers forming a large ear-like cluster. These flowers seemed very attractive to adult Neocrepidodera ferruginea, and such attraction was reported by the early authors Fabricius [60] and Olivier [18]. Adults were also collected on the flowers of other plants: buttercup (Ranunculus acris), common St. John's-wort (Hypericum perforatum), purple loosestrife (Lythrum salicaria), small ragweed (Ambrosia artemisiifolia), various unspecified asters (Aster spp.), New England asters (Aster novae-angliae), various goldenrods (Solidago spp.), water cress (Nasturtium officinale), white sweet-clover (Melilotus alba), and wild carrot (Daucus carota) (Table 1). These plants are probably not 
actual hosts, but alternative food sources for maturation feeding by adults. Such alternative feeding preference is noticeable and well known in corn leaf beetles (Diabrotica spp.). For instance, adults of the northern corn leaf beetle (Diabrotica barberi, Smith and Lawrence, 1967) migrate outside corn fields to feed on the pollen of various plants, preferably goldenrods (Solidago spp.), even though the larvae prefer corn. Such migration was observed in many corn fields located on both sides of Highway 20, between Montréal and Québec city in Québec [61]. According to Naranjo [62], adults stay in corn fields as long as the quality and the quantity of corn pollen is good and acceptable, but move outside when pollen is rare or of poor quality. Apparently, the adults of $N$. ferruginea behave in a similar manner, but more information is needed to confirm these preliminary observations.

\section{Parasites}

Unknown.

\section{Predators}

Unknown.

\section{Economic Importance}

Ahlberg [63] stated that following a dry spring, injury by flea beetles was unusually severe in Sweden in 1941. Barley and spring wheat, and to a lesser extent winter wheat and rye, were damaged by overwintering adults of Phyllotreta vittula (Redtenbacher, 1849). However, the larvae that occur low down in straw in late summer were not those of $P$. vittula as previously thought, but those of Neocrepidodera ferruginea, which was considered a serious pest in Sweden. Johansson [64] observed that the leaves of wheat which turned yellow and ceased to grow, contained larvae of Chaetocnema aridula Gyllenhal, 1827 and C. hortensis (Geoffroy 1785) and also $N$. ferrugine. However, he considered the latter of little importance, even though it may infest cereals and wild grasses.

In England, Gough [65] found Neocrepidodera ferruginea larvae in only nine fields during a survey of 136 fields of winter wheat, in Yorkshire, two-thirds of which were on light soils. Attacked wheat plants exhibited yellow central shoots, while the leaves remained green. Such symptoms were observed, in March, in only 3\% of the fields. According to Jones and Jones [21], the normal host plants are thistles and related plants, but larvae may enter wheat plants by accident while searching for suitable hosts through the soil. Davies [22] reported extensive damage to spring oats, variety Forward in the Ruthin district of Denbighshire. Very few wireworms, or fruit fly larvae (Oscinella spp.; Diptera, Chloropidae) were found in oat stems, but larvae of $N$. ferruginea were numerous within the yellowed central shoots examined in the laboratory. In the field, damage appeared as large patches where plants had been considerably thinned.

In north-east Scotland, Shaw [20] reported damage to the winter wheat variety Cappelle and oats, in April. Areas with extensive thinning necessitated resowing. Where damage was significant, almost every damaged stem revealed a larva, but it was extremely difficult to find larvae inside oat stems, although some were found in the soil after much searching. The following year, Shaw and Osborne [66] reported extensive damage in a 20-acre field of the winter wheat variety Cappelle at Dirleton, east Lothian.

\section{Discussion}

Due to its small size, inconspicuous color, and still undetermined economic impact, Neocrepidodera ferruginea has remained unnoticed until now. On the basis of the available specimens, we believe that it was introduced in early 1970s, or even earlier in the 1960s, at an undetermined international port located on the Great Lakes [67]. The ports on Erie, ON or Huron Lake appear to be the most probable introduction sites since they are the closest to Niagara Falls, Ontario, Canada, where the first specimens were found. On the other hand, those on Lake Michigan or Lake Superior cannot be excluded if we suppose that $N$. ferruginea followed an introduction pattern similar to that of the cereal leaf beetle, which was probably introduced at an international port on Lake Michigan between 1947 and 1949, and positively identified only 15 years later, and has since been expanding eastward and westward [44].

In about 35 years, Neocrepidodera ferruginea moved eastward and reached the Ottawa Valley most likely by natural dispersal, a distance of about $375 \mathrm{~km}$ from Niagara Falls, where the first specimens were collected. Aylmer, on the north shore of the Ottawa River, is presently the northernmost known location of this flea beetle; however, we suspect that it has already established further north from this locality. In Ontario, it would be crucial to determine if it is moving westward towards the Canadian Prairies.

The attraction of Neocrepidodera ferruginea adults to the flowers of various plants is similar to that of the adults of the northern corn leaf beetle, which migrate outside corn fields to feed on the pollen of goldenrods and other weeds [68]. However, $N$. ferruginea do not have to migrate far outside fields since most weeds are ubiquitous and grow within fields in the company of cultivated grasses. Consequently, adults can easily move from one plant species to another and adjust their food preferences to the flowering sequence of weeds which varies with habitats and localities.

\section{Abbreviations}

CBUM: Centre sur la biodiversité de l'Université de Montréal, Montréal, QC, Canada H1X 2B2. S. LeTirant

CFIA: Canadian Food Inspection Agency

CFIM: Collections en Fiducie de l'Insectarium de Montréal, Insectarium de Montréal, Montréal, QC, Canada H1X 2B2. S. LeTirant

CNC: Canadian National Collection, Agriculture Canada, Ottawa, ON, Canada K1A 0C6. L. LeSage 
DAO: Department of Agriculture Ottawa. Official acronym of the Herbarium of the Department, Central Experimental Farm, Ottawa. Amanda Ward

ECORC: Eastern Cereal and Oilseed Research Centre, Agriculture, Ottawa, ON, Canada K1A 0C6

SAMC: S.A. Marshall Private Collection, Department of Environmental Biology, University of Guelph, Guelph, ON, Canada N1G 2W1. S.A. Marshall.

\section{Acknowledgments}

Thanks to Bruce Gill (CFIA), Yolande Dalpé (ECORC), and Vasily Grebennikov (CFIA) for allowing us to use their photographic equipments. The habitus photograph is by Klaus Bolte (Bio Imaging). The comments and constructive suggestions on the paper of Andrés Baselga (Universidad de Santiago de Compostela, Spain), C. G. Majka (Nova Scotia Natural History Museum), and Erhard Dobesberger (CFIA) were greatly appreciated as well as the help of Mauro Daccordi (Museo Civico di Storia Naturale, Verona, Italy) for the translation of Italian documents. Specimens of grasses collected by the authors were kindly identified by Paul Catling (ECORC) and Stephen Darbyshire (ECORC); voucher specimens are deposited in the department herbarium, in Ottawa (DAO).

\section{References}

[1] J. A. Scopoli, Entomologia Carniolica Exhibens Insecta Carniolice Indigena et Distributa in Ordines, Genera, Species, Varietates, Methodo Linnoeana, Trattner, Vindobonae, Austria, 1763.

[2] L. LeSage, "An improved technique for collecting large samples of arthropods," Entomological News, vol. 102, pp. 97-104, 1991.

[3] E. L. Geoffroy, Histoire abrégée des insectes qui se trouvent aux environs de Paris; dans laquelle ces animaux sont rangés suivant un ordre méthodique, Tome premier, Durand, Paris, France, 1764.

[4] L. Chevrolat, "Chrysomélines," in Catalogue des Coléoptères de la collection de M. le comte Dejean, P. F. A. M. Dejean, Ed., pp. 383-455, Méquignon-Marvis Père et Fils, Paris, France, 3rd edition, 1837

[5] L. Chevrolat, "Crepidodera," in Dictionnaire Universel d'Histoire Naturelle, d'Orbigny, Ed., vol. 4, p. 334, Renard, Martinet et Cie, Paris, France, 1844.

[6] A. C. M. E. Foudras, "Altisides," in Histoire naturelle des Coléoptères de France, Mulsant, Ed., vol. 7, pp. 17-128, Annales de la Société linnéenne de Lyon, 1860.

[7] M. Biondi, "Revisione del sottogenere Asiorestia Jacobson s. str. (Coleoptera, Chrysomelidae, Alticinae)," Bollettino del Museo Civico di Storia Naturale Verona, vol. 17, pp. 1-56, 1993.

[8] S. Maulik, The faune of British India, including Ceylon and Burma. Coleoptera. Chrysomelidae (Chrysomelinae and Halticinae), Taylor and Francis, London, UK, 1926.

[9] G. G. Jakobson, "Chrysomelidae (Coleoptera) palaearctici novi vel parum cogniti," Annuaire du Musée Zoologique de l'Académie des Sciences de l'USSR, vol. 26, pp. 231-276, 1926.
[10] M. Biondi, "Classification and phylogenesis of the western Palaearctic species of the genus Asiorestia Jacobson," Entomography, vol. 6, pp. 519-529, 1989.

[11] B. Gruev and M. Döberl, "General distribution of the flea beetles in the Palaearctic Subregion (Coleoptera, Chrysomelidae: Alticinae)," Scopolia, vol. 37, pp. 1-496, 1997.

[12] B. Gruev and M. Döberl, General distribution of the flea beetles in the Palaearctic Subregion (Coleoptera, Chrysomelidae: Alticinae) Supplement, Pensoft, Moscow, Russia, 2005.

[13] A. S. Konstantinov and N. J. Vandenberg, Handbook of Palearctic flea beetles (Coleoptera: Chrysomelidae: Alticinae), Associated Publishers, Gainsville, Fla,USA, 1996.

[14] F. Heikertinger, "Die Halticinengattung Neocrepidodera (nov. gen.)," Archiv für Naturgeschichte, vol. 77, supplement 1, pp. 34-38, 1911.

[15] M. Pic, "Descriptions ou diagnoses et notes diverses (suite)," L'Échange, Revue Linnéenne, vol. 25, pp. 153-156, 1909.

[16] M. Jacoby, "Descriptions of the phytophagous Coleoptera of Japan obtained by Mr. George Lewis during his second journey, from February 1880 to September 1881. Part II. Halticinae and Galerucinae," Proceedings of the Zoological Society of London, vol. 53, no. 4, pp. 717-755, 1885.

[17] A. F. Fourcroy, Entomologia parisiensis, sive catalogus Insectorum, quae in agro parisiensi reperiuntur; secundum methodum Geoffraeanam in sectiones, genera et species distributus; cui addita sunt nomina trivialia et fere trecentae novae species, Paris, France, 1785.

[18] A. G. Olivier, "Entomologie, ou histoire naturelle des insectes, avec leurs caractères génériques et spécifiques, leur description, leur synonymie et leur figure enluminée," p. 491, Coléoptères, Baudonia, Tome VI, Paris, France, 1808.

[19] G. du Chatenet, Coléoptères phytophages d'Europe, tome 2, Chrysomelida, N.A.P. Editions, Verrières le Buisson, France, 2002.

[20] M. W. Shaw, "The wheat stem flea beetle, Crepidodera ferruginea Scop. damaging winter and spring cereals in north-east Scotland," Entomologist's Monthly Magazine, vol. 96, p. 246, 1960.

[21] F. G. W. Jones and M. G. Jones, Pests of Field Crops, Edward Arnold, London, UK, 1964.

[22] T. G. Davies, "Wheat stem flea beetle, Crepidodera ferruginea Scop. damage in cereals in North Wales," Entomologist's Monthly Magazine, vol. 100, p. 69, 1964.

[23] H. Blunck, "Zur Kenntnis der Lebensgewohnheiten und der Metamorphose getreidebewohnender Halticinen," Zeitschrift fur Angewandte Entomologie, vol. 19, pp. 282-357, 1932.

[24] M. L. Cox, Atlas of the Seed and Leaf Beetles of Britain and Ireland (Coleoptera, Bruchidae, Chrysomelidae, Megalopodidae and Orsodacnidae), Pisces, Newbury, UK, 2007.

[25] S. Doguet, "Michel Bergeal, un coléoptériste passioné," Nouvelle Revue d'Entomologie, vol. 20, pp. 199-203, 2010.

[26] E. G. Riley, S. M. Clark, R. W. Flowers, and A. J. Gilbert, "124. Chrysomelidae Latreille 1802," in American beetles. Volume 2: Scarabaeoidea through Curculionoidea, R. H. Arnett, M. C. Thomas, P. E. Skelley, and J. H. Frank, Eds., p. 861, CRC Press, Boca Raton, Mass, USA, 2002.

[27] A. Warchalowski, Palaearctic Chrysomelidae. Identification keys, Natura Optima Dux Foundation, Warszawa, Poland, 2010.

[28] A. Warchalowski, Chrysomelidae, The leaf-beetles of Europe and the Mediterranean area, Natura optima dux Foundation, Warszawa, Poland, 2003.

[29] S. Doguet, Faune de France 80. Coléoptères Chrysomelidae. Vol. 2.: Alticinae, Fédération Française des Sociétés de Sciences Naturelles, 1994. 
[30] A. Baselga and F. Novoa, "The Western Palaearctic Neocrepidodera (Coleoptera: Chrysomelidae) of the N. impressa and N. ferruginea species groups," Annals of the Entomological Society of America, vol. 98, no. 6, pp. 896-907, 2005.

[31] I. Löbl and A. Smetana, Catalogue of Palaearctic Coleoptera: Vol. 6 Chrysomeloidea, Appollo Books, Stenstrup, Denmark, 2010.

[32] L. LeSage, "Family Chrysomelidae-leaf beetles," in Checklist of beetles of Canada and Alaska, Y. Bousquet, Ed., p. 430, Research Branch, Agriculture Canada, Ottawa, 1991.

[33] E. G. Riley, M. C. Shawn, and T. N. Seeno, Catalog of the Leaf Beetles of America North of Mexico (Coleoptera: Megalopodidae, Orsodacnidae and Chrysomelidae, Excluding Bruchinae), Coleopterists Society Special Publication, 2003.

[34] D. A. Ogloblin and L. N. Medvedev, "The larvae of the leaf beetles (Coleoptera, Chrysomelidae) of the European part of the USSR," Opredeliteli po Faune SSSR, vol. 106, pp. 1-122, 1971.

[35] L. N. Medvedev and Y. M. Zaitsev, The larvae of chrysomelid beetles of Siberia and the Far East, Nauka, Moscow, Russia, 2nd edition, 1978.

[36] W. R. Steinhausen, "Status of Palaearctic Alticinae larvae research (Coleoptera: Chrysomelidae)," Spixiana, supplement 7, pp. 39-42, 1982.

[37] W. R. Steinhausen, "Chrysomelidae Larven," in Die Larven Der Käfer Mitteleuropas 2. Band Myxophaga Polyphaga Teil 1. 17. Überfamilie Chrysomeloidea 116. Familie: Chrysomelidae, B. Klausnitzer, Ed., pp. 231-314, Goecke \& Evers, Krefeld, Germany, 1994.

[38] W. J. Brown, "Some new Chrysomelidae, with notes on other species (Coleoptera)," The Canadian Entomologist, vol. 78, pp. 47-54, 1946.

[39] L. Lesage, "(Note on the present and future distribution of the lily leaf beetle, Lilioceris lilii (Scopoli) ( Coleoptera: Chrysomelidae) in eastern Canada)," Naturaliste Canadien, vol. 110, no. 1, pp. 95-97, 1983.

[40] L. LeSage and B. Elliott, "Major range extension of the lily leaf beetle (Coleoptera: Chrysomelidae), a pest of wild and cultivated Liliaceae," Canadian Entomologist, vol. 135, no. 4, pp. 587-588, 2003.

[41] C. G. Majka and L. LeSage, "Introduced leaf beetles of the maritime provinces, 5: The lily leaf beetle, lilioceris lilii (Scopoli) (Coleoptera: Chrysomelidae)," Proceedings of the Entomological Society of Washington, vol. 110, no. 1, pp. 186-195, 2008.

[42] D. L. Haynes, S. H. Gage, and W. Fulton, "Management of the cereal leaf beetle pest ecosystem," Quaestiones Entomologicae, vol. 10, pp. 165-176, 1974.

[43] D. L. Haynes and S. H. Gage, "The cereal leaf beetle in North America," Annual Review of Entomology, vol. 26, pp. 259-287, 1981.

[44] L. LeSage, E. J. Dobesberger, and C. G. Majka, "Introduced leaf beetles of the Maritime Provinces, 2: The cereal leaf beetle Oulema melanopus (Linnaeus) (Coleoptera: Chrysomelidae)," Proceedings of the Entomological Society of Washington, vol. 109, no. 2, pp. 286-294, 2007.

[45] Watford Coleoptera Group, "WCG, Website of the Watford Coleoptera Group," 2011, http://www.thewcg.org.uk/.

[46] H. Blunck, Handbuch der Pflanzenkrankheiten. Fünfter band. Tierische Schädlinge an Nutzpflanzen, 2, Paul Parey, Berlin, Germany, 1954.

[47] L. Bedel, Faune des Coléoptères du bassin de la Seine, Vol. 5. Phytophaga (fasc. 4), Annales de la Société Entomologique de
France, Publication hors série [1889-1901], 423, Paris, France, 1899.

[48] A. Balachowsky and L. Mesnil, "Crepidodera ferruginea Scop. (Col. Halticidae)," in Les insectes nuisibles aux plantes cultivées, A. Balachowsky and L. Mesnil, Eds., pp. 806-807, Ministère de l'Agriculture, 1935.

[49] A. Lameere, Manuel de la Faune de Belgique. Tome II, Insectes Inférieurs, H. Lamertin, Bruxelles, Belgium, 1900.

[50] N. H. Joy, A Practical Handbook of British Beetles, vol. 1, E.W. Classey, Faringdon, UK, 1976.

[51] M. Biondi, "Le specie appenniniche del genere Crepidodera Chevrolat sensu Foudras (Coleoptera, Chrysomelidae, Alticinae)," Bollettino del Museo Civico di Storia Naturale Verona, vol. 8, pp. 45-66, 1982.

[52] B. Gruev and V. Tomov, Fauna Bulgarica 16 : Coleoptera, Chrysomelidae II : Chrysomelinae, Galerucinae, Alticinae, Hispinae, Cassidinae, Sofia, Bulgaria, 1986.

[53] A. Gök and E. G. Çilbiroğlu, "Some smaller genera of flea beetles (Coleoptera: Chrysomelidae) from western Turkey with a new record," Phytoparasitica, vol. 32, no. 5, pp. 444450, 2004.

[54] A. Bukejs, "To the knowledge of flea beetles (coleoptera: Chrysomelidae: Alticinae) of the fauna of Latvia. 3. Genera Neocrepidodera heikertinger, 1911 and crepidodera chevrolat, 1836," Acta Zoologica Lituanica, vol. 19, no. 2, pp. 109-119, 2009.

[55] F. Kutschera, "Beiträge zur kenntnis der europäischen Halticinen," Wiener Entomologische Monatschrift, vol. 3, pp. 112-121, 1860.

[56] E. Allard, "Monographie des Alticides (Chrysomélides)," L'Abeille Journal d'Entomologie, vol. 3, pp. 181-428, 1866.

[57] E. Favre, Faune des Coléoptères du Valais et des régions limitrophes, Zurich, Imprimerie Zurcher \& Furrer, 1890.

[58] Germplasm Ressources Information Netweork (GRIN) Taxon: Cirsium lanceolatum (L.) Scop, 2011, http://www.arsgrin.gov/cgi-bin/npgs/html/taxon.pl?419844.

[59] Germplasm Ressources Information Netweork (GRIN) Taxon: Triticum vulgare Vill, 2011, http://www.ars-grin.gov/cgi-bin/ npgs/html/taxon.pl?40640.

[60] J. C. Fabricius, Species Insectorum Exhibens Eorum Differentiasm Specificas, Synonyma Auctorum, Loca Natalia, Metamorphosis, Adiectis Observationibus, Tome I. Hamburgi et Kilonii, Carol Ernest Bohini, 1781.

[61] L. LeSage, "Noticeable increase in the abundance of the Northern Corn Rootworm in Ontario and Quebec in 1984," The Canadian Agricultural Insect Pest Review, vol. 62, no. 19, 1984.

[62] S. E. Naranjo, "Flight orientation of Diabrotica virgifera virgifera and D. barberi (Coleoptera: Chrysomelidae) at habitat interfaces," Annals of the Entomological Society of America, vol. 87, no. 3, pp. 383-394, 1994.

[63] O. Ahlberg, "Årets jordloppshärjningar," Växtskyddsnotiser, no. 4, pp. 53-59, 1943.

[64] E. Johansson, "Injury to cereals by flea-beetle larvae," Växtskyddsnotiser, no. 6, pp. 88-89, 1942.

[65] H. C. Gough, "A note on the occurrence in Yorkshire of Celaena (Apamea) secalis L. (Lep., Caradrinidae), Opomyza germinationis L. (Dipt., Opomyzidae) and Crepidodera ferruginea Scop. (Col., Chrysomelidae) in winter wheat," Entomologist's Monthly Magazine, vol. 83, p. 130, 1947.

[66] M. W. Shaw and P. Osborne, "Further damage to cereals in Scotland by the wheat stem flea beetle, Crepidodera ferruginea Scop. (Col., Chrysomelidae)," The Entomologist's Monthly Magazine, vol. 97, p. 203, 1961. 
[67] GLIN Great Lakes Information Network, 2011, http://www .great-lakes.net/.

[68] J. E. Cinereski and H. C. Chiang, "The pattern of movements of adults of the Northern Corn Rootworm inside and ouside corn fields," Journal of Economic Entomology, vol. 61, pp. 15311536, 1968. 

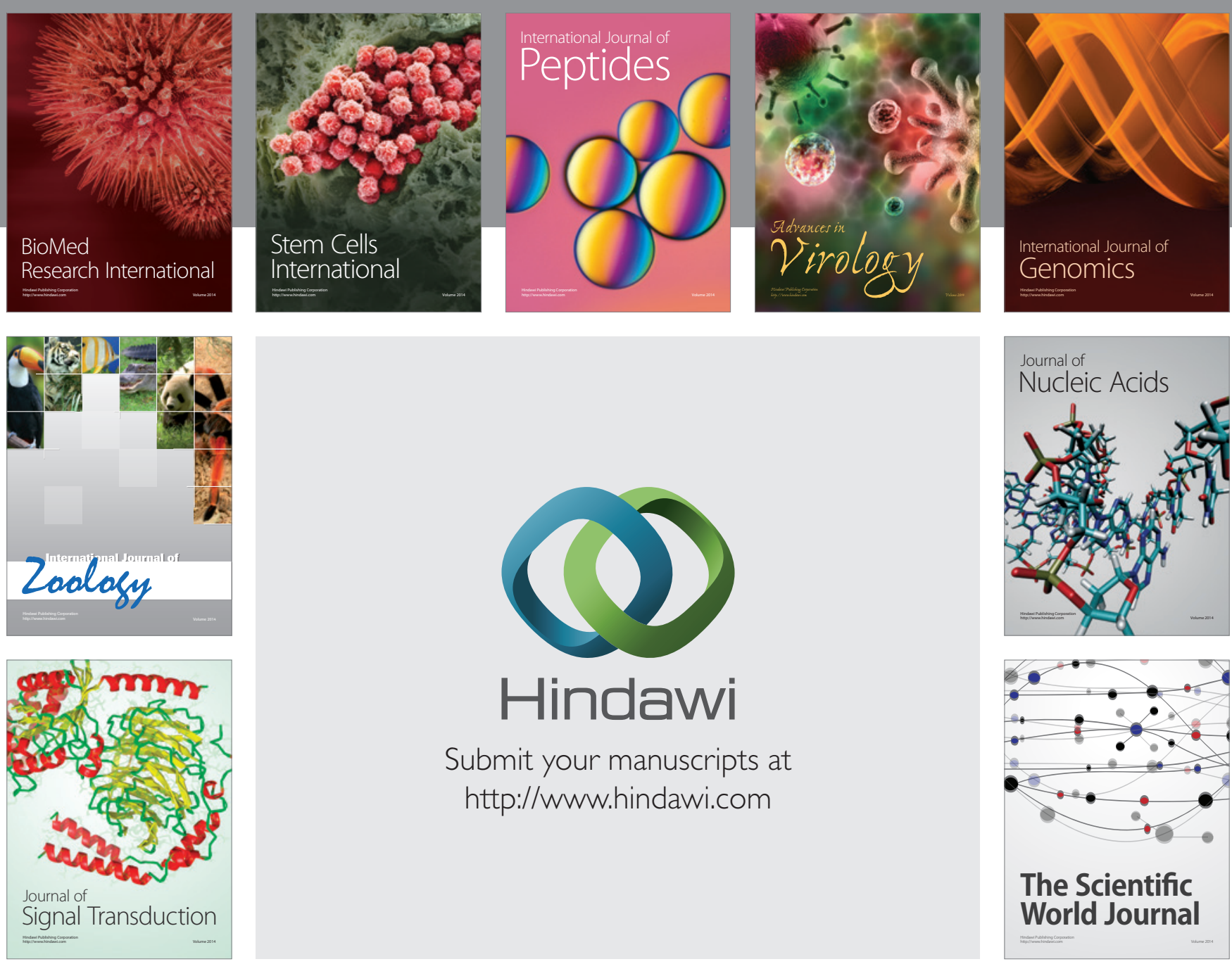

Submit your manuscripts at

http://www.hindawi.com
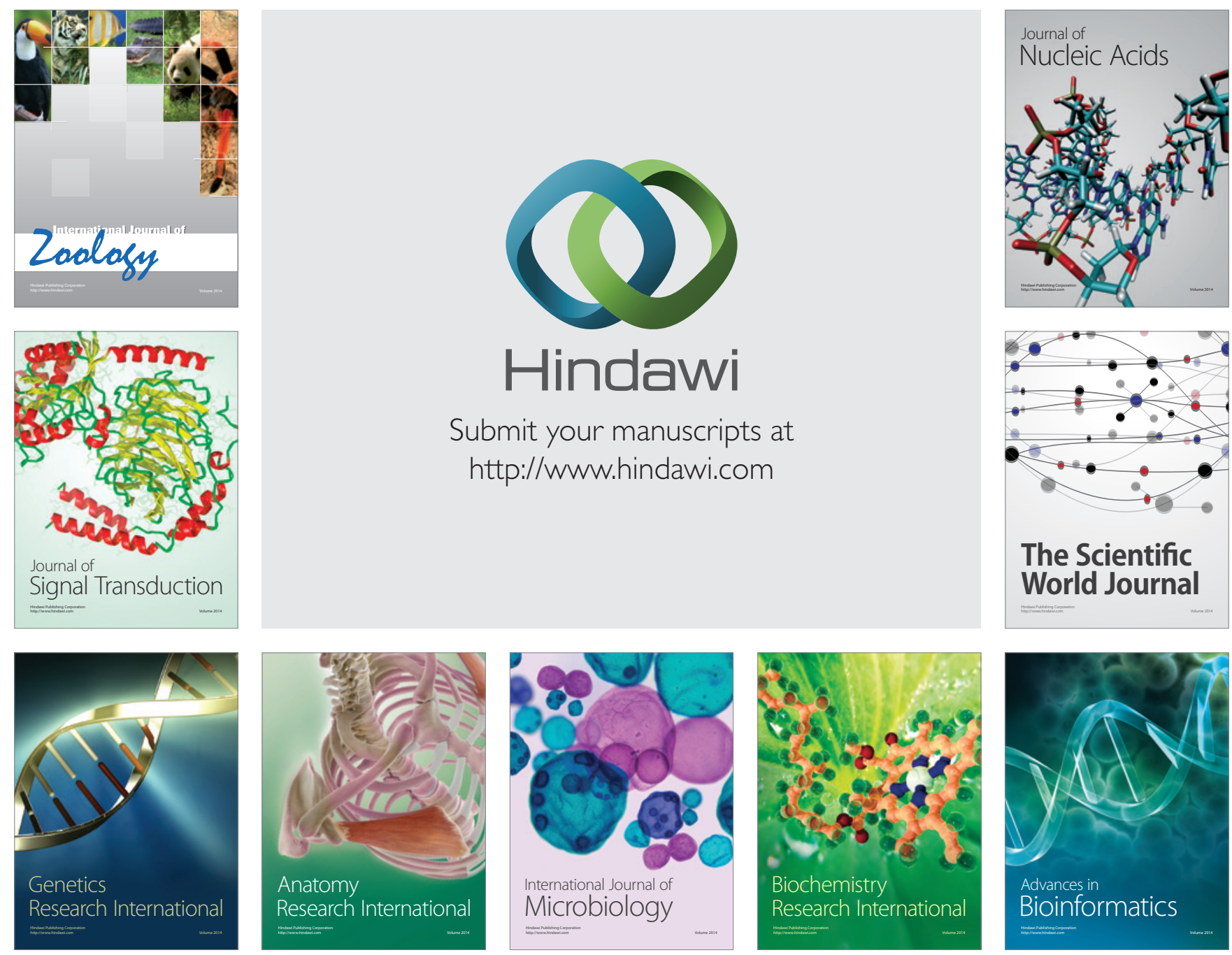

The Scientific World Journal
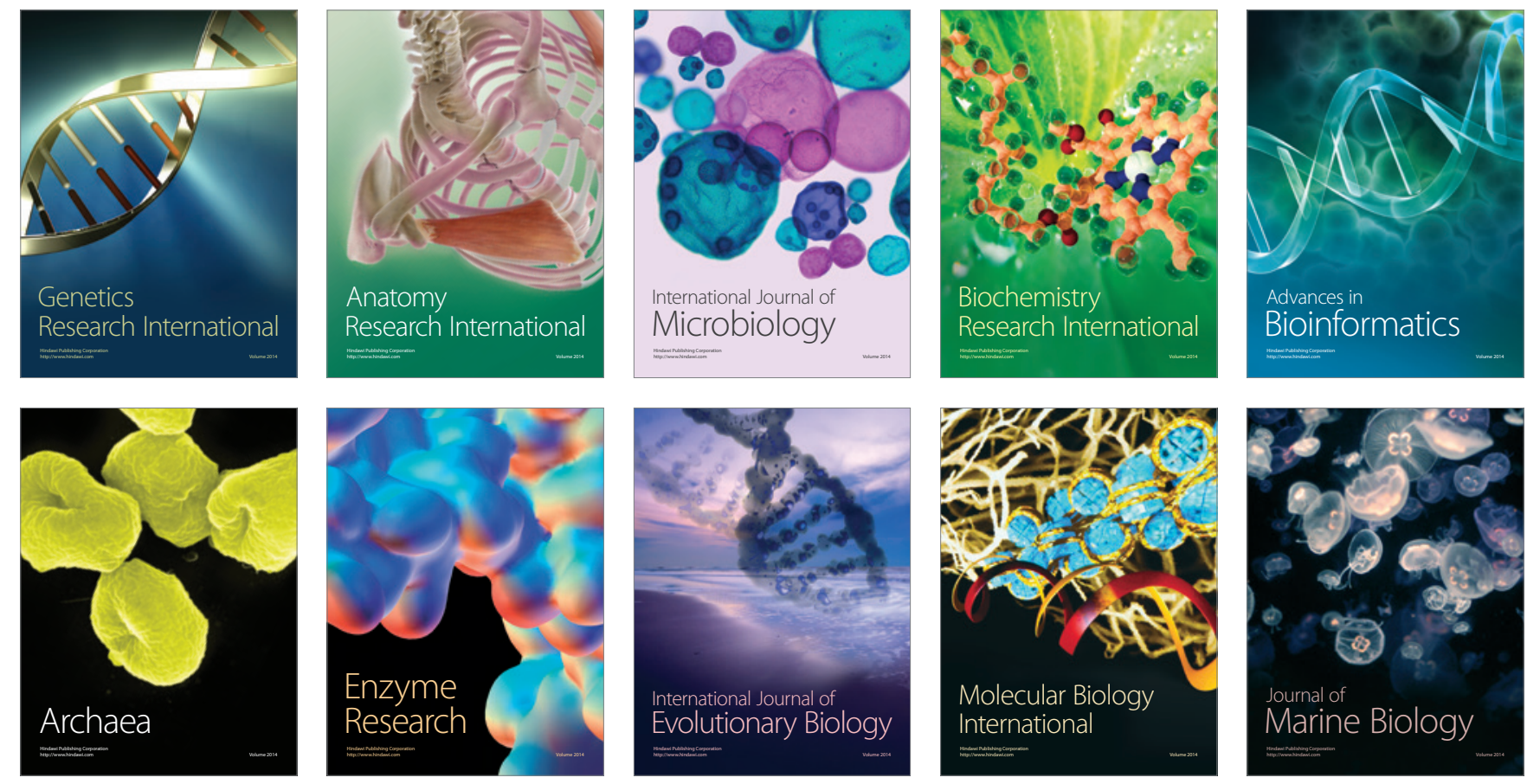